\title{
Discovery of obsidian mines on Mount Chikiani in the Lesser Caucasus of Georgia
}

\author{
Paolo Biagi ${ }^{1, *}$, Renato Nisbet ${ }^{1} \&$ Bernard Gratuze $^{2}$
}

\section{Introduction}

The volcanic Javaketi Range (Lesser Caucasus, Georgia) has recently aroused the interest of both geologists and archaeologists on account of its rich environmental and geological history, the prehistoric exploitation of its raw materials and the discovery of archaeological sites ranging from the Palaeolithic to the Historical Ages (Gogadze 1980; Kikodze 1983). In 2012 and 2014, two systematic surveys were conducted on Mount Chikiani (Koyundağ) with the aim of defining the areas from which obsidian was obtained during different prehistoric periods, and to characterise its sources (Biagi \& Gratuze 2016). A longer season of archaeological prospection was carried out in 2016. Among the many important finds was the discovery of a large number of obsidian mining pits along the northern and northeastern lower slopes of the volcano (Figure 1), as well as several obsidian workshops. During the 2016 season, research focused on the $2417 \mathrm{~m}$-high trachyrhyolitic dome-a source of high-quality obsidian - emerging from the plain around $300 \mathrm{~m}$ north-east of Lake Paravani.

The Middle-Late Pliocene volcano, composed of trachyrhyolites, obsidians and perlites (Nasedkin et al. 1983) is characterised by acidic lava flows whose age is still debated (Lebedev et al. 2008; Le Bourdonnec et al. 2012; Nomade et al. 2016; Lebedev \& Vashakidze in press), although it seems to be no older than $2.8 \mathrm{Ma}$ and not more recent than 2.4 Ma. The quality of the obsidian is excellent-homogeneous with no inclusions—and it occurs in a variety of colours.

Evidence from Ortvale Klde in north-western Georgia suggests that Chikiani obsidian was occasionally used from the end of the Middle Palaeolithic (Le Bourdonnec et al. 2012), but it was used much more extensively during the Early Neolithic to the Iron Age, as documented by finds from dozens of sites lying between the Black Sea and the Caspian Sea (Alikemek-tepesi in eastern Trans-Caucasia; Badalyan et al. 2004).

At Chikiani today, obsidian is easy to access. The only obstacle to its exploitation is the thick snow cover that lasts more than six months of the year. At present, the area is treeless mountain steppe, but pollen analysis of sediments from Lake Paravani

1 Department of Asian and North African Studies, Ca' Foscari University of Venice, Ca' Cappello, San Polo 2035, I-30125 Venezia, Italy

2 Institut de Recherche sur les Archéomatériaux, Centre Ernest-Babelon, UMR 5060, CNRS/University of Orléans, $3 D$ rue de la Férollerie, F-45071 Orléans cedex 2, France

* Author for correspondence (Email: pavelius@unive.it)

(C) Antiquity Publications Ltd, 2017 ANTIQUITY 91 357, e5 (2017): 1-8 


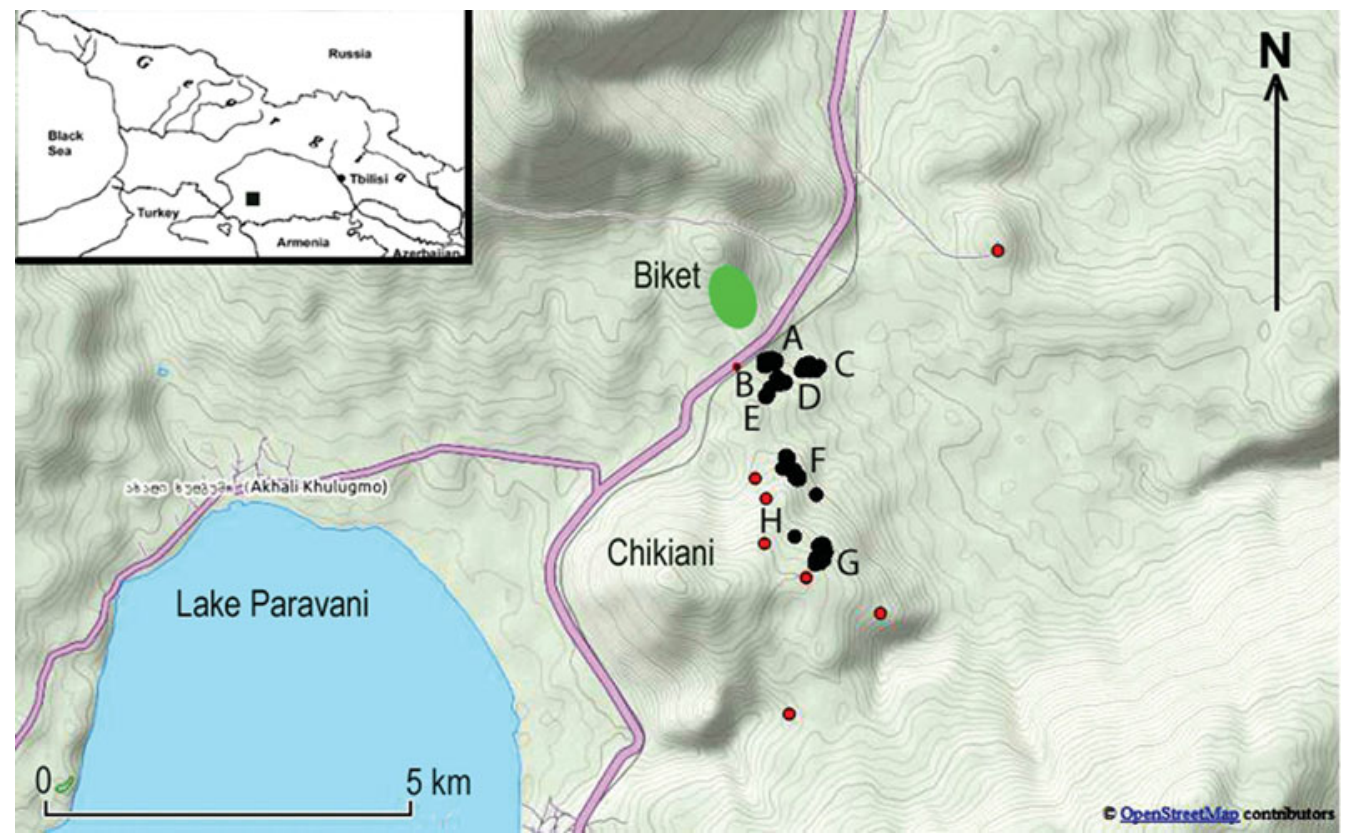

Figure 1. Mount Chikiani: distribution map of the different groups of obsidian mining pits $A-G$ (black dots) and workshops (red dots) discovered in July 2016, and location of Mount Biketi obsidian spots (R. Nisbet)

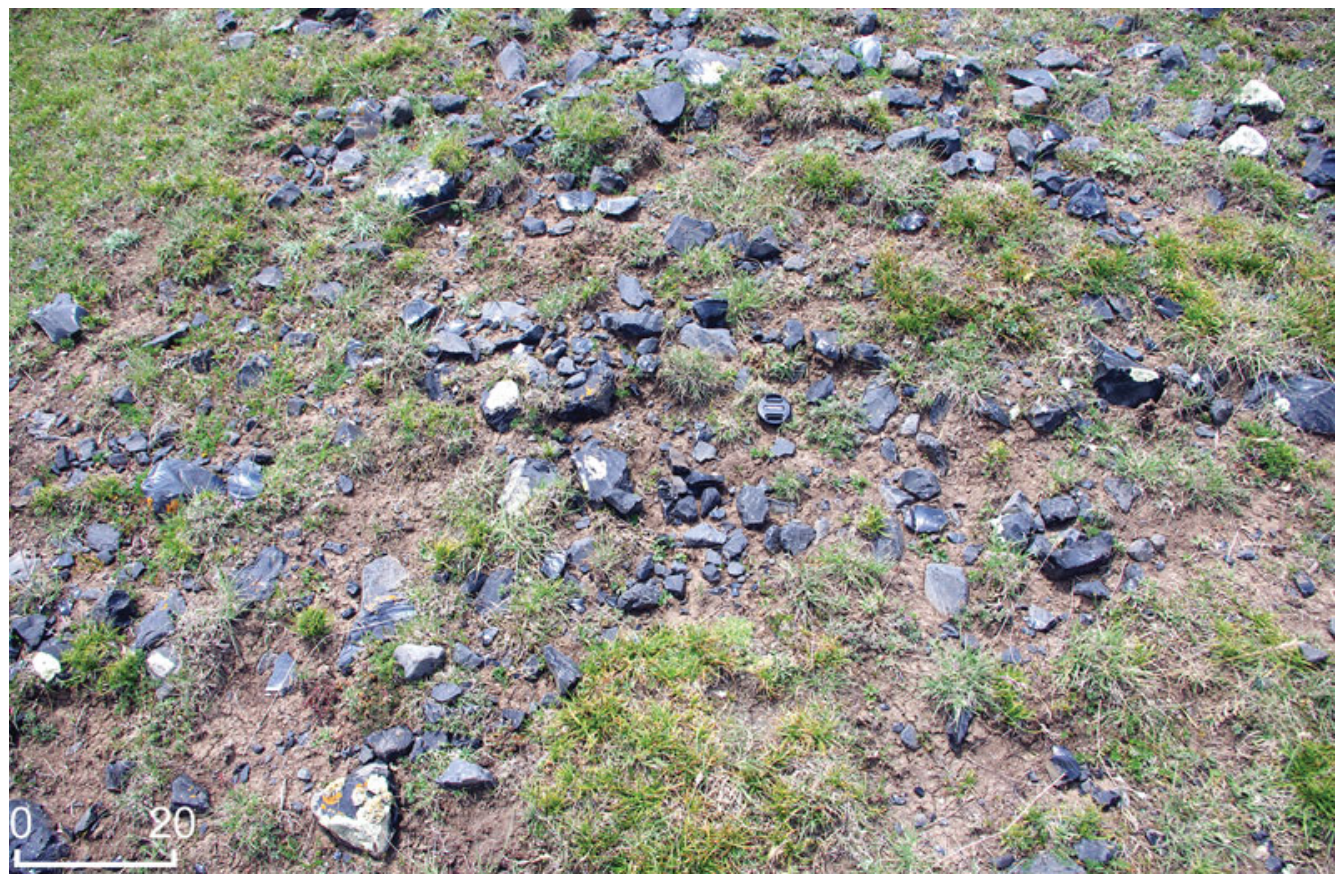

Figure 2. Mount Chikiani: central area of an obsidian workshop along the eastern upper slope of the mountain labelled

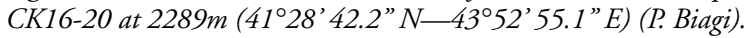

(C) Antiquity Publications Ltd, 2017 


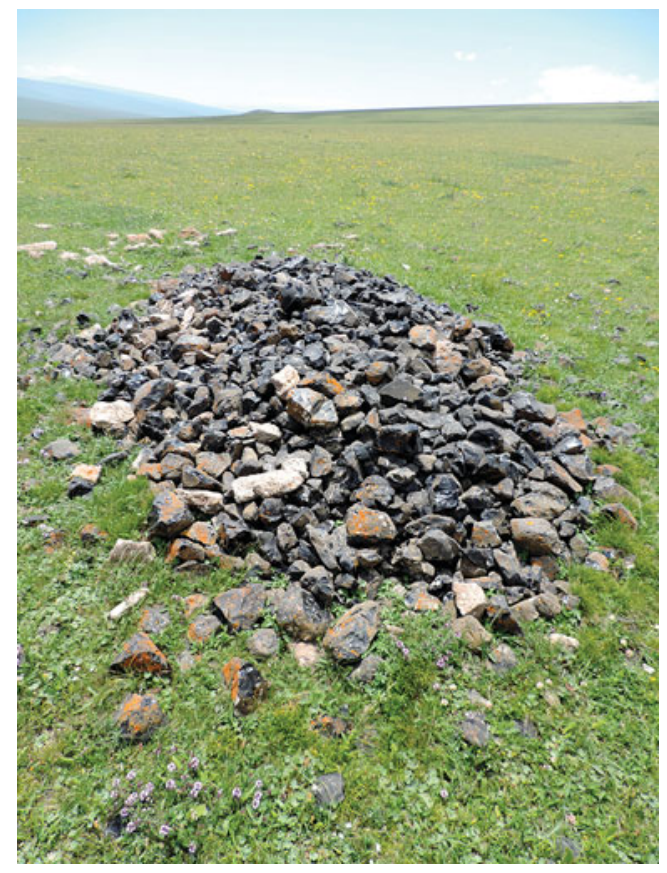

Figure 3. Mount Chikiani: kurgan made of obsidian blocks (P. Biagi).
(Messager et al. 2013) and from a Bronze Age kurgan to the west of the lake (Kvavadze \& Kakhiani 2010) show that the region was forested until at least 2000 BP. Access to Chikiani obsidian, however, is also possible through the Chrami River. Tributaries flowing down the slopes of the massif transport pieces of obsidian into the river and down to its lower course where sites of the Neolithic ShulaveriShomutepe culture, dated to the sixth millennium cal BC, are located (Badalyan et al. 2004).

Characterisation of the obsidian samples collected in 2012 and 2014, mainly along the eastern flanks of the mountain (see Biagi \& Gratuze 2016: fig. 6), identified three different compositional groups, showing that various flows were exploited during prehistory, even though the manner and period of their exploitation are still to be defined.

\section{The 2016 survey}

During July 2016, the area around Chikiani was surveyed, mapping all visible archaeological features and collecting obsidian samples. The principal results are the identification and mapping of:

a) Seven previously unknown workshops, mostly along the northern and north-eastern slopes of the dome (Figure 1). They consist of obsidian scatters including sub-conical blade cores, flakes, blades, a few retouched tools and debitage (Figure 2).

b) A new area rich in obsidian artefacts, mainly unretouched flakes along the lower slope of Mount Biketi (Biket), 3km north of Mount Chikiani.

c) More than 100 kurgans of different size and shape, some of which are made exclusively of obsidian blocks (Figure 3), and several monumental stone alignments, one of which is more than $100 \mathrm{~m}$ long.

d) Around 240 shallow pits, mostly $2-5 \mathrm{~m}$ in diameter, on the northern and north-eastern sides of Mount Chikiani. These are interpreted as evidence of prehistoric mining. To date, eight clusters of pits (A-H in Figure 1) have been located, lying between $2160 \mathrm{~m}$ and $2293 \mathrm{~m}$. Under good light conditions, they are clearly visible from a distance, running down the slopes (Figure 4 bottom). The pits are round or oval in shape (Figure 4 top), surrounded by low banks of excavated debris, frequently containing knapped obsidian flakes, sometimes tools and sub-conical cores. Obsidian samples from 

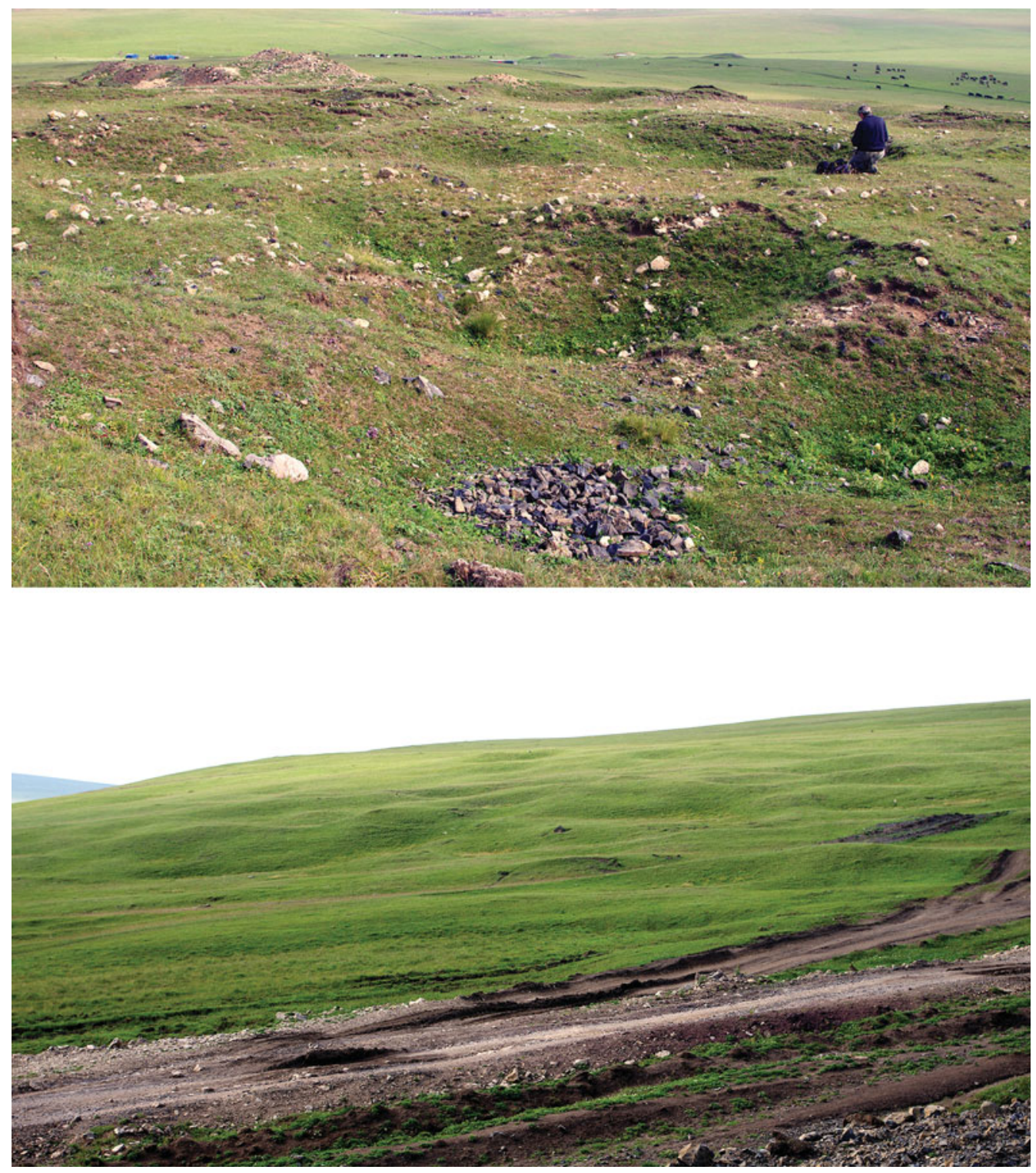

Figure 4. Mount Chikiani: obsidian mining area $G$ (bottom) and obsidian extraction pits mapped within mining area $F$ (top) (P. Biagi).

18 of these features have been analysed at CNRS, IRAMAT laboratory of Orléans University, France.

\section{Discussion}

The size, shape and distribution of the mining pits suggests that preliminary testing and knapping of the obsidian blocks was undertaken at or very close to the extraction pits.

(C) Antiquity Publications Ltd, 2017 

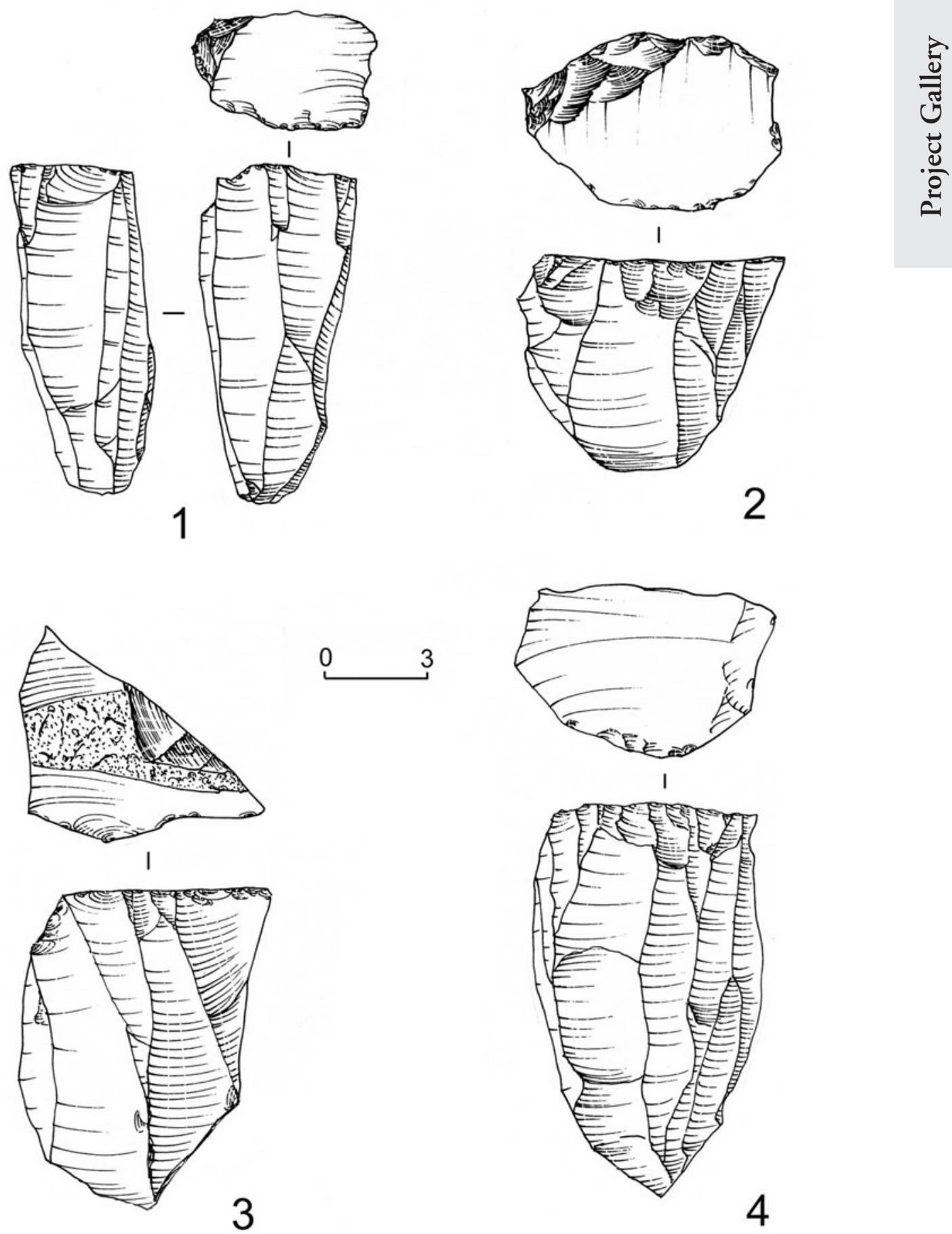

Figure 5. Mount Chikiani: obsidian blade cores from the mining-pits CKMD-7 (no. 1), CKMG-1 (nos 2 and 4) and workshop CK16-22 (no. 3) (P. Biagi and E. Starnini).

(C) Antiquity Publications Ltd, 2017 

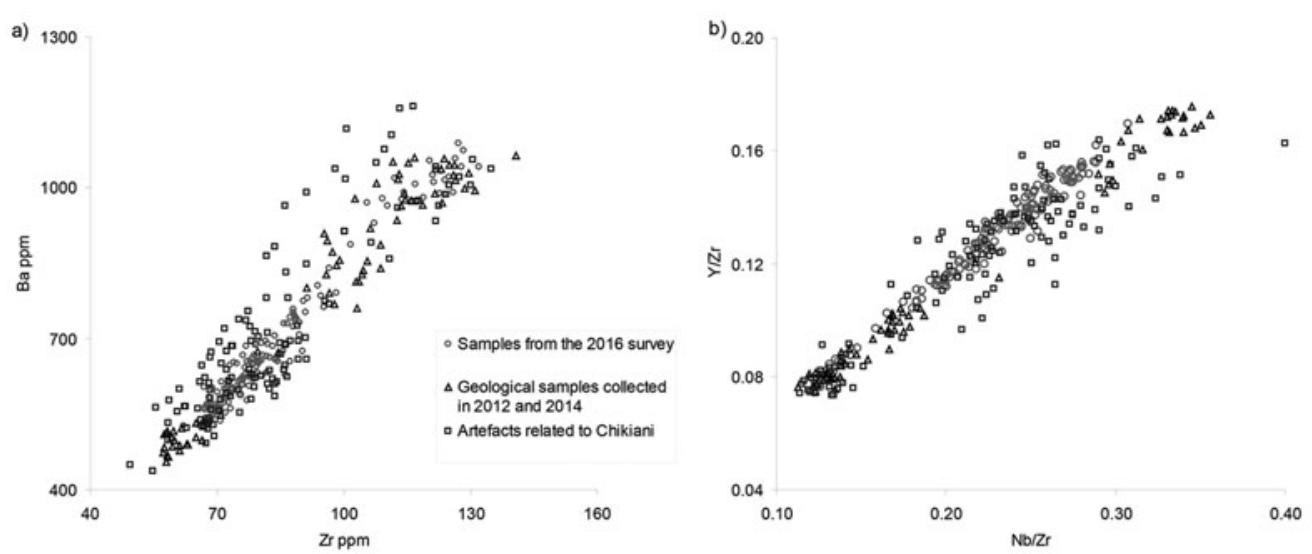

Figure 6. Mount Chikiani: binary diagram of the $Z r$-Ba contents (a) and of the $Y / Z r-N b / Z r$ ratios (b) of the 2016 geological corpus compared to our previous values (2012-2014 surveys) and those of the archaeological artefacts (B. Gratuze).

The characteristics of the obsidian cores and tools (long, sub-conical cores with prepared platforms and indirect percussion blade detachments (Figure 5), plus a few flat-retouched instruments) recovered around these features appear to relate to different periods of the Kura-Araxes Culture of the Chalcolithic and the Bronze Ages (e.g. Kushnareva 1997; Palumbi \& Chataigner 2014). In contrast, 'workshops' are found at some distance from the extraction pits. Analysis is still ongoing, but the artefacts from these sites, including blades with parallel sides obtained by pressure technique, would suggest a Neolithic date for at least some of these features.

The discoveries at Chikiani shed new light not only on regional obsidian circulation, but also on the organisation of the acquisition and processing of raw materials, as already discussed for other regions of the Near and Middle East (Gopher \& Barkai 2014). Furthermore, it contributes to the study of the complexity of the Chalcolithic and Bronze Age societies of the Caucasus and neighbouring regions-this is the first evidence for obsidian mining fields recorded in this area-and emphasises the continued importance of knappable materials during the Metal Ages. This fact had been remarked upon in other regions of Eurasia (e.g. Delage 2003, 2007; Allard et al. 2008; Bostyn \& Giligny 2014). In particular, studies of the Bronze Age Indus Valley civilisation (Biagi \& Starnini 2008; Starnini \& Biagi 2011) have paid strong attention to the fundamental importance of knappable materials, and to the effort, organisation, labour and techniques involved in their procurement, manufacture, distribution and trade.

The characterisation of the specimens collected during the 2012 and 2014 surveys shows some compositional differences from the artefacts attributed to Mount Chikiani. Figure 6 indicates chemical compositions intermediate to groups defined by the geological samples previously collected. The new results obtained from the 2016 samples are in better agreement with the compositions of the artefacts. This demonstrates the importance of this newly surveyed area for obsidian supply during the Chalcolithic and Bronze Ages, and most probably for part of the Neolithic period too.

(C) Antiquity Publications Ltd, 2017 
During the last two years, many perlite quarries have been opened on the slopes of the volcano. Regrettably, these have already damaged the heritage of Mount Chikiania unique archaeological landscape that so far finds no parallel elsewhere in the Caucasus.

\section{Acknowledgements}

Thanks to V. Licheli (I. Javakhishvili Tbilisi State University, Georgia) for his assistance and support for the 2012 and 2014 surveys. The 2016 fieldwork was made possible thanks to the financial support of Ca' Foscari University of Venice Archaeological Research Funds, and EURAL Gnutti (Rovato, Brescia, I). We are also grateful to the I. Javakhishvili Tbilisi State University students who took part in the 2014 and 2016 surveys. Thanks are further due to V.A. Lebedev (IGEM, Russian Academy of Sciences, Moscow, Russian Federation) for his critical reading of the original text and information on the geological structure of Mount Chikiani.

\section{References}

Allard, P., F. Bostyn, F. Giligny \& J. Lech (ed.). 2008. Flint mining in prehistoric Europe. Interpreting the archaeological records (British Archaeological Reports international series 1891). Oxford: Archaeopress.

Badalyan, R.S., C. Chataigner \& P. Kohl. 2004. Trans-Caucasian obsidian: the exploitation of the sources and their distribution, in A. Sagona (ed.) A view from the highlands. Archaeological studies in honour of C. Burney (Ancient Near Eastern Studies 12): 437-65. Leuven: Peeters.

Biagi, P. \& B. Gratuze. 2016. New data on source characterization and exploitation of obsidian from the Chikiani area (Georgia). Eurasiatica 6: 9-35. https://doi.org/10.14277/6969-093-8/EUR-6-1.

Biagi, P. \& E. Starnini. 2008. The Bronze Age Indus quarries of the Rohri Hills and Ongar in Sindh (Pakistan), in R.I. Kostov, B. Gaydarska \& M. Gurova (ed.) Geoarchaeology and archaeomineralogy: 77-82. Sofia: St Ivan Rilski.

Bostyn, F. \& F. Giligny (ed.). 2014. Lithic raw materials resources and procurement in the pre-and protohistoric times (British Archaeological Reports international series 2656). Oxford: Archaeopress.

Delage, CH. (ed.). 2003. Siliceous rocks and prehistory bibliography on geo-archaeological approaches to chert sourcing and prehistoric exploitation (British Archaeological Reports international series 1168). Oxford: Archaeopress.

- 2007. Chert availability and prehistoric exploitation in the Near East (British Archaeological Reports international series 1615). Oxford: Archaeopress.

Gogadze, E.M. 1980. Excavations at Paravani Kurgan (1979). Archaeological Expeditions of the Georgian National Museum 7: 42-48 (in Georgian and Russian).

Gopher, A. \& R. Barkai. 2014. Middle Paleolithic open-air industrial areas in the Galilee, Israel: the challenging study of flint extraction and reduction complexes. Quaternary International 331: 95-102. https://doi.org/10.1016/j.quaint.2013.08.025.
Kikodze, Z.K. 1983. On the methods of study of the Early Palaeolithic bifaces. Sovetskaya Arxeologiya 3: 188-94 (in Russian).

Kushnareva, K.Kн. 1997. The Southern Caucasus in prehistory. Stages of cultural and socioeconomic development from the eighth to the second millennium $B C$ (University Museum Monograph 99). Philadelphia: The University Museum, University of Pennsylvania.

Kvavadze, E.V. \& K. Kakhiani. 2010. Palynology of the Paravani burial mound (Early Bronze Age, Georgia). Vegetation History and Archaeobotany 19 (5-6): 469-78. https://doi.org/10.1007/s00334-010-0259-x

LeBedeV, V.A. \& G.T. VAShakidze. In press. Geochronological constraints for young volcanism of Samsari Ridge and Tsalka Plateau (Javakheti Highland, Republic of Georgia). Quaternary International. https://10.13140/RG.2.1.4649.0329.

Lebedev, V.A., S.N. Bubnov, O.Z. Dudauri \& G.T. Vashakidze. 2008. Geochronology of Pliocene volcanism in the Dzhavakheti Highland (the Lesser Caucasus). Part 2: eastern part of the Dzhavakheti Highland. Regional geological correlation. Stratigraphy and Geological Correlation 16(5): 553-74. https://doi.org/10.1134/S0869593808050080

Le Bourdonnec, F.-X., S. Nomade, G. Poupeau, H. Guillou, N. Tushabramishvili, M.-H. Moncel, D. Pleurdeau, T. Agapishvili, P. Voinchet, A. Mgeladze \& D. Lordkipanidze. 2012. Multiple origins of Bondi Cave and Ortvale Klde (NW Georgia) obsidians and human mobility in Transcaucasia during the Middle and Upper Palaeolithic. Journal of Archaeological Science 39: 1317-30. https://doi.org/10.1016/j.jas.2011.12.008

(C) Antiquity Publications Ltd, 2017 
Messager, E., S. Belmecheri, U. Von Grafenstein, S. Nomade, V. Ollivier, P. Voinchet, S. Puaud, A. Courtin-Nomade, H. Guillou, A. Mgeladze, J.-P. Dumoulin, A. Mazuy \& D. Lordkipanidze. 2013. Late Quaternary record of the vegetation and catchment-related changes from Lake Paravani (Javakheti, South Caucasus). Quaternary Science Reviews 77: 125-40.

https://doi.org/10.1016/j.quascirev.2013.07.011

Nasedkin, V.V., N.N. Sergeev, G.Ya. Alibegashvili \& L.G. Rixiladze. 1983. Geological structure of the Paravani perlite deposit, in Geology and genesis of the most important endogenic non-metallic deposits: 186-98. Moscow: Nauka (in Russian).
Nomade, S., V. Scao, H. Guillou, E. Messager, A. Mgeladze, P. Voinchet, P.R. Renne, A. Courtin-Nomade, J.M. BardintzefF, R. Ferring \& D. Lordkipanidze. 2016. New ${ }^{40} \mathrm{Ar} /{ }^{39} \mathrm{Ar}$, unspiked $\mathrm{K} / \mathrm{Ar}$ and geochemical constraints on the Pleistocene magmatism of the Samtskhe-Javakheti highlands (Republic of Georgia). Quaternary International 395: 45-59. https://doi.org/10.1016/j.quaint.2015.05.049

Palumbi, G. \& C. Chataigner. 2014. The Kura-Araxes Culture from the Caucasus to Iran, Anatolia and the Levant. Between unity and diversity. A synthesis. Paléorient 40: 247-60.

Starnini, E. \& P. Biagi. 2011. The archaeological record of the Indus (Harappan) lithic production: the excavation of RH862 flint mine and flint knapping workshops on the Rohri Hills (Upper Sindh, Pakistan). Journal of Asian Civilizations 34(2): 1-61. 